\title{
The Work of Albanian Poet Dritëro Agolli from the Evaluative Point of View \\ Vjollca Rrapai
}

\author{
Faculty of Education and Social Sciences, Department of Albanian Literature, Gjirokastër, Albania \\ vjollcarapai@yahoo.com \\ Sashenka Kamberi \\ Faculty of Education and Social Sciences, Department of Albanian Language, Gjirokastër, Albania \\ sashakamberi@yahoo.com
}

\section{Doi:10.5901/ajis.2015.v4n2p155}

\section{Abstract}

Dritëro Agolli is one of the best poets of Albanian literature, who has given immense pleasure to different generations with his verses. The realist themes, love for his country and for the honest people and also the subtle lyricism are some of the characteristics of his poetic works. He has given an invaluable contribution to the creation of real aesthetic values and also to the development and cultivation of Albanian language. The social and political conditions of the country have had their effect on the inspiration of the poet, who for a long time believed in "the communist ideal and dream." The fall of the communist regime and the political changes in the country impacted his work and of course the evaluative point of view. The aim of this paper is to show how literary critics have evaluated his poetry and him over the years emphasizing the fact that real art triumphs over any kind of political point of view. Dritëro Agolli is today a great personality and a founding father of the real values and modern Albanian poetry.

Keywords: poetry, themes, criticism, socialist realism ideology.

\section{Introduction}

Dritëro Agolli is a worthy representative of modern Albanian poetry. He strongly influenced the creation of aeshtetic values of this poetry, by contributing a great wealth to Albanian language and literature. Agolli's poetic work is vast and diverse. In it we find the short poem, the narrative poetry, the ballad, the satirical and light poetry, children's literature, the verse fable etc. His creative mastery testifies to an illustrious creative personality and to a founder of the real values of the new Albanian poetry.

He started writing poetry since he was a child and he continues to bring values to the art of poetic word. He is continuously appreciated and presented with prizes and awards.

The spontaneity of his poetry shows about the importance of reality to the inspiration of the poet, to him experiencing the facts and historic events and also to his dreams about the future. It mirrors not only the soul of the poet, but also the Albanian life over the decades. In fact, his entire work can be called a chronicle of social, cultural and political developments in Albanian life after the Liberation until nowadays. It shows the sensitivity of the poet to every delicate moment that our country has gone through.

Dritëro Agolli is one of the most beloved and widely read Albanian poets by all the age groups. Despite fluctuations, readers at every time have relished the soft mellifluous verse, finding in it also pieces of their worlds and lives. He sang better than anyone could to his country, to the animals and birds, to the trees and flowers and above all to the average Albanian, extolling his work, soul and moral and satirising every flaw.

The way his poetry has been appreciated by the people and the critics has been influenced by the political and social circumstances. He made his debut in the Albanian letters in the $60 \mathrm{~s}$ as an original voice. His philologic formation, his vast knowledge of Albanian language and literature, of many world poets, the translation of poems of foreign poets, but above all his undisputed talent have all influenced his work as a writer. He positioned himself in the group of the poets of the $60 \mathrm{~s}$ who shook the foundations of the poetry of the tradition which belonged to the national liberation war, opening the way to a new kind of poetry.

With the status of an expert in literature, the scholar Sh. Sinani thinks that: Driterro Agolli and the "generation of the 1960s" did not ask for the changes in the writing techniques by presenting rules in the form of a new poetics, but by 
radically impacting the canons of previous Albanian versification. ${ }^{1}$ Since his early poems he became part of the discussions concerning the problems of poetry, becoming a point of reference as far as the debate initiated in newspaper "Drita" was concerned, where were being discussed at length issues of poetry, especially the problems of form, seen from the ratio of tradition to innovation. From the point of view of literary criticism during socialist realism many new phenomena in his poetry were unacceptable. The poet supported his points of view by theoretical arguments. In the article "Tradition, of course, but not a literary mould", published in the newspaper Drita, he expresses his views regarding tradition and new forms in poetry. We,- he writes,- should strip poetry of the redundant words which seem to be poetic, like "trim i rrallë", "shtatvigan", "shqipe e lehtë" and tens of hundreds like these. A lot of our poets have fallen in love with these expressions. Poetry does not need sweet epithets, but powerful figures of bold thinking, artistic detail. ${ }^{2}$ These ideas sparked discussions among the poets and scholars of the time, who shared different opinions regarding tradition and innovation in poetry.

Agolli's literary work has always sparked not only the interest of the common reader but also of the various scholars, despite the fact that the activity of the latter ones does not run parallel to the creative riches of the poet. As GJ. Shkurtaj says: the greatest danger is, taking into account especially the small size of the newspaper articles, to speak about the expressive values of such a great poet, is less than his verse is actually worthy of. ${ }^{3}$ Despite the fact that genuine specialist works of writing like monographs are missing, his poetry has become an object of study for various reasons. The articles which have addressed the thematic and ideological content of the poet are quite a few. Many of these studies are superficial anyway and have amounted to no more than a paraphrase of the content of his poems. A typical example would be analyses of the poems "Devoll, Devoll" and "Poem for my father and me", which have drawn attention mainly for their biographical notes and the relationship of the poet with his birthplace or the unity between the « ego » of the poet and the lyric hero. Verses of this nature have been often used to show te creative originality of the poet, dealing solely with the content, i.e. with the themes, motives, ideas and lyric hero thus avoiding the techniques of his poetry and the undisputed linguistic values which it carries.

His first volumes of poetry were published at a time when poetry had to respect the principles and rules which constituted the aeshtetics of the time.

The scholar Llazar Siliqi in his analysis of the volume "The word engraves the rock" does not agree with the superficial evaluation which is his poetry usually receives. In our literary criticism - says the scholar, has been rather strongly emphasised, the fact that the poet comes from the village, his frequently taking up the theme of the village or his use of the popular poetic work which fully effloresced in the village, sometimes even stating that the work of Agolli is the new content which village population brings into art and literature, leading us to imagine him as a poet of the village. ${ }^{4}$ There have been different interpretations regarding this point of view, which apparently existed in the judgements of the time. In the newspaper "Drita" Ndue Zef Toma explains the popular spirit which permeates his poetry with the fact that: By getting into the the consciousness of the people, he, inevitably, would come to think like them. ${ }^{5}$ As far as the frequent similarity in figuration is concerned, this scholar thinks: it has been created in such manner as the people creates, life is addressed by the poet the same way the people would refract it through the prism of poetic figuration. ${ }^{6}$

The then literary criticism for the most part has aimed at highlighting those poetic values which conformed to the ideology.

The fact that the poet has been a representative of the communist ideal has featured prominently in many poems. Nevertheless there have been critics who were not satisfied with this and emphasised the fact that the entire future transformation of the village on the path to socialism, which has brought about the transformation of the inner world of the villager, it has either not been given at all, or it has been given in a rather evasive manner, mainly through aspects of a simply social and intimate character. ${ }^{7}$ Thus, as we see, there have been cases that the poet has been criticised in the optics of socialist realism, because his poetry does not echo with the politics of the time, because the strong political exclamations are missing and that he labels as enemies only those who posed a threat to national freedom and not the enemies of the classes. In fact, the literary criticism of the time goes so far as to ask the poet to make his poetry more

\footnotetext{
1 Shaban Sinani, "Insane people" by Dritëro Agollit, Tiranë, 2012 p.12

2 Dritwro Agolli, Tradition, of course, but not a literary mould, Drita, 27.VIII.1961.

3 Gjovalin Shkurtaj, Phenomena and novelties of poetic discourse, The weight of the Albanian word, Tiranë, 2009 p.132

${ }^{4}$ Llazar Siliqi, When the word engraves the rock, Drita, 15.V.1977.

${ }^{5}$ N.Z. Toma, Poetry which springs from life, with its burts and joys, Drita, 8.VI. 1980

6 In the same place.

${ }^{7}$ Razi Brahimi, When we talk about poetry, Tiranë, 1972, p.140
} 
educational, it does not even contain the slightest evidence to call upon the small-minded people or to open up life pathways. ${ }^{8}$

At different times his poetry got embroiled in prolonged discussions, which at times supported the poetic values, whereas at other times contradicted everything, labelling it as conformist. So, the political changes of the country have left their mark on his work and undoubtedly on the evaluative optics. After the fall of the communist regime, he has been often criticised for his ideological outlook and his political commitment, something which he has never denied. He became once again the target of unfounded accusations of a nihilistic nature, that rose against everything which had been created before.

Time has come that Dritëro Agolli's poetry be evaluated and re-evaluated objectively through genuine means of aesthetics. Various scholars have begun to shed light on the real values of his decades-long poetry, which they do not see as separate from his life.

According to the scholar M.Gero - Dritëro Agolli has withstood the pedantic ideological storms which used to come from the political circumstances of the time, like he had to face, especially after the 90s, even denigrating and unprincipled attacks, inspired by mediocre and egoistic policies, which he overcame with wisdom, courage and strong will, thanks, above all to his great artistic talent. ${ }^{9}$ Taking into account the "narrow-minded" attacks which he faced in the late 80 s we all agree that the phenomenon Dritëro Agolli once again testifies that true art overcomes any kind of policy. Great art is immortal. ${ }^{10}$

There is no denying to the fact that some of his poems, written before the 90s glorify the communist ideal and dream, which the poet believed in for many years, but this has not detracted from their values. After the fall of the dictatorship, many people with or without the proper formation, in the wake of general outrage opposed the poet and his poetry, with every kind of argument. But, to their amazement and to the fate of Albanian poetry the poet returns stronger with his poetry. This is the return of "the traveller to the place of broken hope" with the pain that the loss of poetic caravan has left behind: I have parted unwillingly from my caravan.../l am from a long time a belated pilgrim, /Wanderer of the lost caravan...,(The belated pilgrim, Tiranë, 1993 p.7). In the volumes of this decade there are no significant refractions, which are connected to the changes between the social and political changes. There are changes in the poetic concerns, but not in the forms and means of expression. ${ }^{11}$ So, the poet faces a new whirlwind of experiences injected by the sociopolitical circumstances. The situation of the poetic ego changes, it loses the past enthusiasm and is overwhelmed by pain, disappointment, alienation, existentialism and the effort for a new oreintation. In the poem "The Epigraph", published in the volume "The belated pilgrim", the poet exercises self-understanding accompanied by a noble orientation:

Me? There in the graveyard.
Mixed with dirt of course.
A stone with black letters:
"Here lies an ex-communist"
Some petty poet might say:
"Hasn't this old dog been eradicated?"
A voice from underground will answer:
"I am the ashes, my master can be found in books"! (p.150)

Truly the creative poetic personality of D.Agolli, cannot be separated from the social and political circumstances in which he was created and formed, ${ }^{12}$ but he is the poet with ideological orientation, who knew how to express with supreme mastery the ideal that he embraced. In every verse of this nature can be felt the sincere love for the country and people, the desire for a better future, the purposeful glorification of Mother Albania.

The scholar Gj.Shkurtaj says: $D$. Agolli is by now a well-known poet who talks with the reader openly, as a man affiliated with a party who is fully aware when he echoes with the great social experiences and changes in the life and mentality of modern man, as an official who keeps clear of bureaucratization and talks simply with the working people, the farmers and shepherds in the same way as he does with poets and writers. ${ }^{13} \mathrm{He}$ finds his ideas from life around him, but

\footnotetext{
8 In the same place.

${ }^{9}$ Mina Gero, Rhyme dictionary of Dritëro Agollit, Introduction, Tiranë, 2013 p. 15

10 In the same place.

11 Shaban Sinani, "Insane people" by Dritëro Agollit, Tiranë, 2012 p.165

12 Diana Çulli, The Poems of Dritëro Agollit, Philological Studies Nr.3, p.91

${ }^{13}$ Gjovalin Shkurtaj, The weight of the Albanian word, Tiranë, 2009, p.137
} 
by avoiding every kind of banality which damages poetry.

\section{Conclusion}

Thus, we come to the conclusion that Agolli is one of those writers who has triumphed with his art over any kind of political point of view, by paying great attention to the language of poetry and poetic word. Today his work is appreciated for its multidimensional values in form as well as in content, however, time has come to re-read the poetry of the time of the dictatorship from another optics. The evaluation of his poetry of the last period is important to know not only the tendencies, changes and the protagonists of new Albanian poetry; but also to make comparisons, to find an answer to the question what happened to the writers of socialist realism when they found themselves outside the ideological discipline, in an open society, with the freedom to create and without methodological canons. ${ }^{14}$

Finally, we can say that the entire literary-linguistic wealth that the poet has generated over the decades, searching with love and perseverance for the word, verse and poetry wherever it was, should be highlighted and be given the values it deserves, by being treated in compliance with the new concepts.

\section{References}

D.Agolli, "Tradition, of course, but not a literary mould", Drita, 27.VIII.1961.

Gj. Shkurtaj, "The weight of the Albanian word", Tiranë, 2009

Gj.Shkurtaj, "Phenomena and novelties of poetic discourse", The weight of the Albanian word, Tiranë, 2009

M. Gero, " Rhyme dictionary of Dritëro Agollit", Tiranë, 2013

D.Çulli, "The Poems of Dritëro Agollit", Philological Studies Nr.3

Sh.Sinani, "Insane people" by Dritëro Agollit, Tiranë, 2012

14 Shaban Sinani, "Insane people" by Dritëro Agollit, Tiranë, 2012, p.158 